\title{
Chapter 6 \\ Social Media and Community Policing Implementation in South Eastern Europe: A Question of Trust
}

\author{
Janina Czapska and Katarzyna Struzińska
}

I. Community policing (COP) is based on close and frequent police-community interactions aimed at solving local security problems. In recent years, a use of social media (SM) within this model of police work increasingly gains in importance (Denef et al. 2012: 22-24). Nevertheless, in post-communist societies, where COP is still relatively new, the use of SM by the police might face challenges related to insufficient public confidence in the law enforcement, and stereotypical negative image of the police officers, who are perceived as more control- than community-oriented.

In this context, SM seem to be a tool that might support the process of improving the police image what, consequently, can lead to an increase of citizens' trust. Owing to the fact that SM enable users to play an active role in the public discourse, they might be an effective measure to bridge gaps in relations between the police and citizens. SM can foster the development of participatory culture by simplifying police-community contact as well as by enabling an effective two-way communication.

In this paper, we analyse chosen quantitative research on police legitimacy, as well as present findings of our field studies in Bosnia and Herzegovina $(\mathrm{BiH})$ which are a part of the EU funded international research project CommunityBased Policing and Post-Conflict Police Reform (ICT4COP; 2015-2020). The empirical part of the paper is based on the chosen qualitative data gathered during research in $\mathrm{BiH}$ in 2016.

Author contributed equally to this paper. Janina Czapska and Katarzyna Struzińska

J. Czapska $\cdot$ K. Struzińska $(\bowtie)$

Department of Sociology of Law, Faculty of Law, Jagiellonian University, Kraków, Poland e-mail: katarzyna.struzinska@uj.edu.pl 
II. Police legitimacy is the declared, or at least presumed, aim of COP implementation that gains particular importance while implementing this strategy in postcommunist countries. Reaching a high level of police legitimacy is connected to an array of positive outcomes, among which we can list enhancing readiness to cooperate with the police and readiness to obey the law. Legitimacy is a permanently under-defined notion. The most general definition frames it as 'the right to rule and the recognition by the ruled of that right' (e.g. Hough et al. 2013: 4). In this initial differentiation is hidden the basic distinction between normative (objective) legitimacy and empirical (subjective) legitimacy. In the normative understanding, legitimacy indicates whether the police meet certain desirable standards (mainly in the framings of lawyers and political philosophers). Police legitimacy in the subjective (empirical) understanding consists in the conviction of the ruled that the ruling has the right to express orders that have to be obeyed.

A challenge for researchers and social politicians is to define what the relation between legitimacy in the normative understanding and in the empirical one can be (is/should be). It is of particular importance in societies undergoing transformation, as at that moment, they often experience anomy and abrupt ideological or legal changes. The history of many such countries demonstrates how dynamically police legitimacy may vary due to political changes.

III. Owing to the growing interest in these issues, today we could announce the coming of an era of 'legitimacy of the police' as research problem undertaken with unprecedented frequency. The differences between particular studies concern the understandings of legitimacy, the relation between legitimacy and trust to the police, the factors that affect legitimacy. The relations between these factors are usually presupposed by researchers in initial models (hypotheses), and the real connections are established on the basis of empirical data.

The diagnosed connections should be the basis for political and legal proposals as to what should be done to reinforce police legitimacy in particular societies. Obviously, it cannot be expected that by using right, context-rooted arguments, according to the assumptions of evidence-based policing, one single right solution can be chosen. Unfortunately, it is not the only problem, as the analysis of studies accessible in mid-2017 leads to the conclusion that the understandings of each of the studied factors become increasingly unclear, and the possibility of comparing or formulating hypotheses on the basis of existing studies is decreasing.

The analysis of the ways in which studies frame the relations between such variables as: trust to the police, legitimacy, legality of action, procedural justice, distributive justice, efficiency of the police, sharing common values with the police, readiness to cooperate with the police, legal cynicism, behaviours compliant with the law, sense of obligation to obey orders, leads to the conclusion that questionnaires often ask the same questions and only in the statistical analysis of the results the answers are linked to one another and labelled differently.

It seems that researchers agree as to the 'account of the dynamic and interactive nature of legitimacy' (Bottoms and Tankebe 2012); the dialogue continues between the police and the society. It is very challenging to attempt to answer the question whether, while trying to establish what legitimacy is, what factors affect it and what outcomes it may have, it is possible to distinguish specific features of post-conflict 
countries in a methodologically correct way with the current state of knowledge. The most important ways of arriving at the answers as to what legitimacy of the police is can be characterized in the following way on the basis of exemplary research carried out in the past few years:

(a) The concept of police legitimacy constructed for the fifth round (R5) of the research conducted in EU member states for the European Social Survey (ESS) is based on the assumption that perceived legitimacy could be understood as a multidimensional concept involving consent (the obligation to obey the police), moral alignment (sharing common values by the citizens and the police) and lawfulness (legality of the police actions). 'Trust' is not an element of 'legitimacy' but trust to select aspects of the police/the police officers' actions can influence the level of legitimacy. The research distinguished trust to: procedural justice, distributive justice, and the police efficiency.

Comparing the answers to particular questions in these studies does not allow us to determine a clear profile of the so-called post-communist countries but in particular questions differences between this category of countries and other countries can be noticed. In other cases, the citizens of the so-called post-communist countries give answers identical to those of the citizens of e.g. Southern European ones. However, the method of analysis, consisting in applying multiple factors of certain constructs should be used with great caution, as 'a lack of evidence potentially compromises any substantive cross-national comparisons' (Jackson et al. 2013: 188). In the analysed studies, it turned out that the strongest influence on each component of legitimacy was exercised by procedural justice.

(b) Research on police legitimacy in Central and Eastern Europe (CEE) with the participation of Bosnia and Herzegovina and Serbia have been conducted so far usually among students of higher school; the first research was carried out in 2013 among law students coming from eight countries of CEE (Meško et al. 2016; Lukić et al. 2016). Police legitimacy was deemed there to be a two-element concept (felt obligation and trust in the police) and other variables connected to this issue were taken into consideration as well, in particular: procedural justice, the police efficiency, distributive justice, the probability of sanction, moral credibility, legal cynicism, and the following were assumed as potential outcomes: cooperation with the police, readiness to obey the law.

A comparison of the countries indicates statistically significant differences among all countries for: police legitimacy, the police efficiency, willingness to cooperate with the police, procedural justice and moral credibility (Lukic et al. 2016: 426). The authors of the research explained that legitimacy and trust in the police are related to the state of democracy in the studied countries (Meško et al. 2016: 79-80), which was analysed more in-depth on the example of differences between Slovenia and Serbia which had reformed their police differently. However, it was observed that: 'It is surprising that both student groups have a similar opinion about the police in their countries.' (Lukić et al. 2016: 433). An explanation as to what role is played in forming opinions by historical, systemic and cultural differences between particular societies can be brought by further studies. Similarly to the ESS, almost in all countries of CEE, the strongest influence on subjective police legitimacy and its particular components was exercised by procedural justice. Some 
later research with the use of the same method has also been carried out among students from Sarajevo (Muratbegović et al. 2014).

(c) In the study of Serbian students conducted in 2014 (Zekavica and Kesetovic 2015), the initial model comprised ten aspects of legitimacy which were then operationalized usually with questions used in previously conducted studies, but the variables created on their basis were labelled in different ways. The most important aspects of the way in which students perceive police legitimacy are: their perception of the distribution of the police services, the nature and the quality of those services, the perception of the police, the confidence in the police work, and, finally, the perception of the legality of the police work; obedience (felt obligation) was not included in this research category (Zekavica and Kesetovic 2015: 39).

IV. In conclusion, the analysis of the research and of the used models of police legitimacy does not provide a satisfying answer to the questions what legitimacy is, what it depends on, what it influences in particular societies, and what is its relation to trust to the police. However, it allows us to notice the variety of approaches and formulate questions for further research. Among them, the most important are: the role and understanding of trust to the police; possible differentiation between general trust to the police and trust to particular aspects of their work; roles played in forming police legitimacy by the opinions on the police effectiveness and its fulfillment of the conditions of procedural or distributive justice. In countries in transformation, it is important to consider the significance of 'legal cynicism', to determine how it influences the process of forming attitudes towards the police and, in particular, on readiness to cooperate with them. In search for specific features, it is also worth verifying the thesis that the efficiency of social institutions has a significant impact on the perception of legitimacy in these countries (Lukić et al. 2016: 422). In the case of societies in transformation, the problem lies in the re-definition of the basic role of the police. We believe that the most significant change which has been taking place was the one from a 'force' to a 'service' orientation. Consolidating the conviction that the police's role is that of a service-provider, and it is not an 'authority,' as militia had been treated previously, in the social consciousness is emblematic in the process of the police's development in countries that undergo transformation.

It is of utmost importance to determine what role is played by the type and quality of contacts with the police in forming their legitimacy. It seems that hitherto only contacts of a direct character of victims or witnesses have been studied, little attention has been paid in the process of studying police legitimacy in the context of communication via Internet, and via SM in specific. Particular attention needs to be paid to adolescents, for whom the virtual reality is usually a 'natural' environment. At the same time, some specific characteristics of adolescents need to be taken into consideration, in particular, an 'anti-authority syndrome' (Lukić et al. 2016: 422).

The state of knowledge on police legitimacy and building trust to them via SM has an array of weaknesses - we know too little about it, as the studies conducted so far in South Eastern Europe concerned mostly students. Also, they were of quantitative character; it seems then that research on legitimacy is dominated by statistics. We still know very little about what both sides of the interaction, that is the police and the citizens, think about using the media in mutual relations. Are SM mainly supposed to help the society control the police, form the police's image, or just 
serve as a channel of information? These still unclear questions will be analysed on the basis of our qualitative studies in Bosnia and Herzegovina.

V. Within the ICT4COP project, 59 in-depth interviews with experts from state, entity and community level institutions have so far taken place in $\mathrm{BiH}$. The key goal of this article is to present these research results which are related to information and communication technology (ICT), in particular, to the ways in which social media have been so far and might be in the future used by the police. For the purpose of this article, we decided to limit a scope of our empirical analysis and concentrate it on one of two main entities with an extensive autonomy of which $\mathrm{BiH}$ consists, namely, on Federation of Bosnia and Herzegovina (FBiH).

Results presented in this paper come from 25 in-depth interviews conducted in $\mathrm{FBiH} .11$ of them were conducted with respondents representing various state, entity and cantonal level institutions, both public and nongovernmental, in Sarajevo. At the local level, two venues of a different character were studied in the same canton. In the first one, a rural municipality, 4 interviews took place. In the other, an urban municipality, 10 interviews with 11 respondents were conducted.

VI. All interviews in $\mathrm{FBiH}$ were conducted in line with the same, beforehand prepared guidelines. Regardless the level at which research was conducted, during each interview some questions about ICT were asked (e.g. questions about typical ways of communication between the police and citizens; specific ICT tools used by the police to communicate with citizens; opinions on the ICT influence on policecommunity relations, possible ICT solutions which should be used by the police in the future). All respondents were asked at least two questions about ICT; most frequently they answered questions about ways of police-citizen communication and ICT tools used by the police. Taking into account that ICT tools are only one of many possible ways of communication, we decided to start the part of interview dedicated to ICT with checking what the most popular forms of police-community interactions are. This general question was aimed at checking if respondents will describe only traditional ways of police-citizens communication, or they will spontaneously start to talk about modern communication solutions. Answers given by most of the interviewees, regardless the type of institution they represented, were consistent and indicated that police-community communication still takes mainly traditional forms, and happens mostly in the context of an offence being perpetrated.

Majority of respondents named phone calls as the main mean of exchanging information between the community and the police - it was noticed that citizens are rather reluctant to contact the police, and in most cases, they do this only when they have to report a crime. In such a context telephone was claimed to be the fastest way to contact the police. According to the majority of respondents, the other widespread form of police-community communication is face to face communication, which can be initiated not only by the citizens but also by police officers. Almost a half of respondents noticed as well that it might be possible to contact the police via police's web pages and to get some information from them. Nevertheless, it has to be noticed that the police in these parts of $\mathrm{FBiH}$ where our research was conducted do not have own official web pages and the Internet sources to which the interviewees referred were in fact portals of ministries of interiors - institutions to which 
police forces are subordinated. SM were mentioned only once in the context of monitoring them by the police to glean some useful information.

After giving the broader context of the most popular ways in which the police and community exchange information, interviewees were asked about ICT tools that are used by the police to communicate with citizens and to inform them. Respondents who already named some ICT solutions were asked if they know any other tools used by the police. Interviewees most often pointed out the Krimolovci [crime catchers] hotline which enables citizens in the whole country to call the police anonymously and for free to provide them with relevant information. Moreover, relatively frequently web pages of the police, in fact again portals of ministries of interior, and e-mails were named among answers. None of the respondents mentioned spontaneously that the police use SM to communicate with citizens.

All respondents who were asked in specific about SM claimed that they have not been so far used by the police as a mean of communication or that they do not have any knowledge about that. The most frequent answers show that ICT tools used in police-citizens interactions are based on one-sided mechanism of providing the other side with some (potentially) important pieces of information. It seems that for the police in $\mathrm{FBiH}$ there is a still some room for improvements when it comes to a full and active use of the interactive communication possibilities which occurred with the development of modern ICT, especially, of SM.

VII. The use of social media was most thoroughly commented in three cases: (1) by respondents from the police agencies when they talked about obstacles related to this mean of communication; by all respondents, regardless institutions they represented, (2) when they elaborated on the ways Bosnian citizens use SM to communicate with each other about their insecurities, and (3) when they presented opinions about potential impact which SM could have on police-community relations in $\mathrm{FBiH}$.

Firstly, it was noticeable that some police representatives tended to perceive SM usage as a source of new problems for their agency. On the one hand, creating a chance for citizens to communicate with the police in a less formal way via SM was associated with a risk of getting many pieces of facetious or irrelevant information, which would cause an additional and often fruitless work for police officers. On the other hand, some of these respondents seemed reluctant to accept SM because they put the police "more under observation, and under control' of citizens - any behaviour of a police officer can be easily recorded and publish e.g. on Facebook or YouTube. Nevertheless, for some local police officers, the potential use of SM in their daily work was rather abstract, due to the fact that at their police stations access to the Internet is limited or lacking.

Secondly, the majority of respondents emphasized that Bosnian citizens, in particular, young people, rather commonly use SM, especially Facebook, to communicate with each other. One of the respondents as an important aspect of this communication named an ability to create a 'critical mass' of people who '(...) meet up at the social networks in order to react'. Owing to the fact that SM are interactive and easily connect people who are interested in similar issues, they are often used by citizens to create networks which advocate solution of different security-related local problems.

Finally, when asked about the ICT tools which should be used to improve policecitizens relations, respondents, especially ones not related to the police, often pointed out that establishing official police social media profiles will have a positive 
impact on those relations. Interviewees often connected making communication via SM possible with the police becoming more open, transparent and easier to approach. Our research showed that two-way communication in SM is believed to be profitable for both citizens and the police. On the one hand, it gives citizens an easier and more direct way to access the police, not (or not only) in case of emergency, but primarily when they want to share their opinions, ask for advice or find some information. On the other hand, the police can become more visible thanks to SM which can serve them as a new source of knowledge about citizens' needs and opinions as well as a new channel of communication. Furthermore, some respondents noticed that the use of SM can positively influence the image of the police by giving citizens more insight into the police work, as well as by sharing with them some police success stories. In this context, SM seem to be a communication tool which brings the police and the community closer together, and as such, they can play a role in enhancing citizens' trust in the police.

Nevertheless, our research indicates also that despite the potential positive influence of social media on police-community relations, they are not a sufficient tool to increase the trust in the police. Some representatives of international organizations noticed that ICT tools will significantly improve the police-citizens communication only if they are 'built on trust'. Community members who distrust the police will not trust the ICT tools which are used by the police, and will not use them. Our research showed that police have to open up to citizens in the real world to make the best use of the opportunities which are offered by the virtual reality. Some of our respondents believe that to make SM a more effective communication platform, the process of trust building should 'start in the offline world'.

VIII. Expectations, challenges, and hopes related to the potential introduction of social media as a new mean of police-citizens communication in $\mathrm{FBiH}$, which were revealed during our research, reflect the broader spectrum of the issues which are present in the literature on policing and SM. These media can serve the police as a new way to actively connect with the citizens. Due to the fact that they can not only be used to disseminate information but also to initiate both interaction and dialogue that might lead to real cooperation, they seem to be an innovative way to approach COP programmes. Our results are consistent with remarks made by Bain et al. (2014) on the beneficial role which SM can play in building and maintaining a positive image of the police. This role can be pivotal especially in post-communist societies which often need to deal with the insufficient level of police legitimacy. SM seem to be a useful tool which might be used by the police not only as a 'source of criminal information', but also for many other purposes, for instance: transmitting information, interacting and having a two-way communication with citizens or 'showing human side of policing' (cf. Denef et al. 2012: 12-26).

In the presented article we tried to show how various is the empirical image of the legitimacy itself, as well as the relation between police legitimacy and trust in the police. New research studies are necessary to fill the gaps in knowledge about key factors influencing the formation of police legitimacy, especially about police efficiency and procedural justice. Furthermore, the variety of different variables analysed in the research should be taken into account, while setting the aims and methods of police use of SM to communicate with citizens. 
Acknowledgement The Community-Based Policing and Post-Conflict Police Reform (ICT4COP) project presented in this paper received funding from the European Commission, under the call H2020-FCT-2014, Topic FCT-14-2014 Ethical/Societal Dimension TOPIC 2: Enhancing cooperation between law enforcement agencies and citizens - Community policing, under grant agreement number 653909.

\section{References}

Bain, A., Robinson, B. K., \& Conser, J. (2014). Perceptions of policing: improving communication in local communities. International Journal of Police Science \& Management, 17(4), 267-276.

Bottoms, A., \& Tankebe, J. (2012). Beyond procedural justice: A dialogic approach to legitimacy in criminal justice. Journal of Criminal Law \& Criminology, 102, 119-170.

Denef, S., Kaptein, N., Bayerl, P. S., \& Ramirez, L. (2012). Best practice in police social media adaptation. COMPOSITE Project. https://administracionelectronica.gob.es/dam/ jcr:e03b0d77-ed32-4f70-9071-cb6a523236ca/COMPOSITE-social-media-best-practice_1_. pdf.; http://www.composite-project.eu/index.php/1455/items/best-practice-in-police-socialmedia-adaptation-second-report-on-technology-adaption.html.

Hough, M., Jackson, J., \& Bradford, B. (2013). Legitimacy, trust and compliance: An empirical test of procedural justice theory using the European Social Survey. In J. Tankebe \& A. Liebling (Eds.), Legitimacy and criminal justice: An international exploration (pp. 326-352). Oxford: Oxford University Press.

Jackson, J., Kuha, J., Hough, M., Bradford, B., Hohl, K., \& Gerber, M. M. (2013). Trust and legitimacy across Europe: A FIDUCIA report on comparative public attitudes towards legal authority.

Lukić, N., Bajović, V., Tičar, B., \& Eman, K. (2016). Trust in police by Serbian and Slovenian law students: A comparative perspective. Varstvoslovje, Journal of Criminal Justice and Security, 18(4), 418-437.

Meško, G., Fields, C. B., Šifrer, J., \& Eman, K. (2016). Understanding trust in police and legitimacy in Central Eastern Europe: The law student survey. In D. Nogala, K. Neidhardt, T. Görgen, J. Kersten, J.-M. Fiquet, \& G. Meško (Eds.), Policing civil societies in times of economic constraints: European police science and research bulletin (Special conference edition) (pp. 73-80). Münster: European Police College (CEPOL).

Muratbegović, E., Vujović, S., \& Fazlić, A. (2014). Procedural justice, police legitimacy and cooperation of Bosnian students with the police. VARSTVOSLOVJE, Journal of Criminal Justice and Security, 16(4), 387-411.

Zekavica, R., \& Kesetovic, Z. (2015). The legitimacy of the police in Serbia. Journal of Criminalistics and Law, 3, 19-44.

Open Access This chapter is licensed under the terms of the Creative Commons Attribution 4.0 International License (http://creativecommons.org/licenses/by/4.0/), which permits use, sharing, adaptation, distribution and reproduction in any medium or format, as long as you give appropriate credit to the original author(s) and the source, provide a link to the Creative Commons license and indicate if changes were made.

The images or other third party material in this chapter are included in the chapter's Creative Commons license, unless indicated otherwise in a credit line to the material. If material is not included in the chapter's Creative Commons license and your intended use is not permitted by statutory regulation or exceeds the permitted use, you will need to obtain permission directly from the copyright holder.

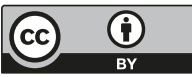

